Підготовка педагогічних кадрів до використання комп'ютерних телекомунікацій / Н.В. Морзе // Комп’ютерно-орієнтовані системи навчання. Вип. 6. - Київ: НПУ ім. М.П. Драгоманова, 2003. - С. 12-25. 7. Про затвердження Порядку надання навчальній літературі, засобам навчання і навчальному обладнанню грифів та свідоцтв Міністерства освіти і науки України. Наказ Міністерства освіти і науки України від 17 червня 2008 року № 537. - Режим доступу: http://www.ukrbook.net/zakony/N_537.htm. 8. Худобець О.А. Чому Інтернет потрібний вчителеві історії / О. А. Худобець //Історія. - 2005. - №5-6. - С. 52-56.

УДК 378.011.3-051:7.071(477)

Олена Пономарьова

\title{
ІНТЕГРАЦІЯ В СИСТЕМІ ПІДГОТОВКИ ФАХІВЦІВ МИСТЕЦЬКИХ СПЕЦІАЛЬОСТЕЙ У ВИЩИХ НАВЧАЛЬНИХ ЗАКЛАДАХ УКРАЇНИ
}

Пономарьова О. М. Інтеграція в системі підготовки фахівців мистецьких спеціальностей у вищих навчальних закладах України

У статті вища мистецька освіта розглядається як поліінтегрована професійно-педагогічна система підготовки фахівців мистецьких спеціальностей у вищих навчальних закладах України, спрямована на збереження, відтворення та примноження суспільно-культурних, культурно-мистецьких, творчо-мистецьких, творчо-виконавських, мистецько-педагогічних, художньо-проектних, естетико-виховних, художньо-естетичних та просвітницьких традицій світової та української культури.

Ключові слова: фахівці мистецьких спеціальностей, мистецтво, вища мистецька освіта, інтеграція, поліінтеграція.

Пономарева Е.Н. Интеграция в системе подготовки специалистов в сфере искусства в высших учебных заведениях Украины.

В статье высшее художественное образование рассматривается как полиинтеграционная профессионально-педагогическая система подготовки специалистов художественных специальностей в высших учебных заведениях Украины, которая направлена на сохранение, воссоздание и приумножение общественно-культурных, культурно-художественных, художественнотворческих, исполнительских, художественно-педагогических, художественно-проектных, эстетико-воспитательных и просветительских традиций мировой и украинской культуры.

Ключевые слова: специалисты в сфере искусства, искусство, высшее образование в сфере искусства, интеграция, полиинтеграция.

Ponomaryova O. M. Integration is in the system of arts specialists training in higher educational establishments of Ukraine.

Higher artistic education is seen by us as a polyintegrated professional and pedagogical system of art specialists training in higher educational institutions of Ukraine aimed at preservation, restoration and augmentation of socio-cultural, cultural and artistic, creative and artistic, creative and performing, artistic and educational, art and design, aesthetic and educational, artistic and aesthetic and educational traditions of world and Ukrainian culture.

Key words: art specialists, art, higher professional arts education, integration, polyintegration.

Освіта в галузі мистецтва $є$ складною, відкритою до змін, розгалуженою системою впровадження професійно-мистецьких, художньо-творчих, ціннісно-естетичних, культурнопросвітницьких, народно-аматорських досягнень у теорію і практику навчально-виховного процесу, спрямованого на здобуття особистістю знань, навичок, умінь і компетенцій професійномистецького, мистецько-педагогічного, художньо-творчого, художньо-виконавського, художньоестетичного спрямування відповідно до завдань різних освітніх і освітньо-кваліфікаційних рівнів підготовки фахівців мистецьких спеціальностей.

Підготовка фахівців мистецьких спеціальностей у вищих навчальних закладах України $є$ процесом і результатом цілеспрямованої професійної художньо-творчої діяльності, культурномистецької практики у поєднанні із теоретичним осягненням закономірностей соціуму, культури, мистецтва і буття відповідно до теоретико-концептуальних основ філософії, 
педагогіки, психології, мистецтвознавства тощо. Такий міждисциплінарний підхід до проблем підготовки фахівців мистецьких спеціальностей пов'язано із інтеграційною природою мистецтва як основи практичної діяльності майбутніх фахівців мистецьких спеціальностей, а також із необхідністю врахування складних умов сучасного суспільства, які відрізняються самоорганізацією, нелінійністю і непередбачуваністю напрямків свого розвитку.

Ураховуючи особливості сучасного соціально-економічного стану розвитку суспільства, інтенсивний розвиток професійно-виробничої інфраструктури, міждисциплінарні науководослідні розвідки й інтегративний характер розвитку глобалізованого суспільства, можемо констатувати, що застосування професійно-мистецьких кадрів у народному господарстві $є$ досить широким, різноплановим. Тому важливого значення набуває рівень готовності професійномистецьких кадрів до праці у нових галузях народного господарства. Тобто нині загострюється проблема інноваційного використання здобутих фахівцем професійних навичок, вмінь і знань на теренах нових професій із застосуванням інноваційних форм і видів художньо-творчої діяльності на основі процесів багаторівневої інтеграції мистецько-освітнього простору.

Проаналізований стан сучасної культури і характер актуалізованих у суспільстві художньоестетичних цінностей надає підстави стверджувати, що сучасне соціокультурне середовище перебуває в тісному взаємозв'язку із художньо-творчими формами та видами взаємодії мистецтва зі світом і довкіллям. Мистецтво як форма пізнання світу та його законів завжди установлює певний зв'язок із будь-якою галуззю людської діяльності. Мистецтво є постійним супутником освітнього процесу взагалі. Використання мистецтва як засобу освітнього процесу $\epsilon$ поліваріативним за характером зв'язків елементів і компонентів систем освіти і мистецтва й сутністю результатів багатоаспектної інтеграції мистецтва, суспільства, культури, освіти і життя.

Мистецтво як вищий щабель розвитку культури людства є складним інтегрованим феноменом, тому доцільно розглядати процес підготовки фахівців мистецьких спеціальностей як цілісну єдину систему взаємозв'язків мистецтва із соціокультурним середовищем, різними галузями наук, художньо-мистецьких практик, форм міжвидової взаємодії мистецтва i мистецької діяльності.

Мистецькі спеціальності розуміються нами як спеціальності, опанування якими студентами спрямовано на здобуття професійних знань, навичок, умінь і компетенцій у процесі фахової підготовки у профільних і непрофільних навчальних закладах за умов організації і управління освітньої діяльності відповідно до сучасних вимог функціонування мистецтва у всьому розмаїтті його видів і типів художньо-творчої діяльності в культурі і соціумі згідно 3 принципами і концепціями державної національно-культурної політики, оскільки відкриття мистецьких спеціальностей на теренах науково-освітнього простору класичних університетів, педагогічних і технічних ВНЗ, стає дедалі звичним явищем, а університети нині стають глобальними самостійними осередками науки, освіти й культури України.

Мистецтво завжди виражає суспільні світоглядні домінанти; чим складнішою $є$ суспільна система, тим складнішим стає розвиток усіх іiї компонентів. 3 цього приводу постає складне питання взаємозв'язків і взаємовпливів системи мистецтва і системи освіти в галузі мистецтва, а якщо врахувати, що мистецтво завжди було потужним компонентом цілісної навчальновиховної системи і цілеспрямовано впливало на розвиток особистості, то впевнено можна стверджуваити, що мистецтво, як вершина людської діяльності, здатне формувати суспільну свідомість, вибудовувати майбутнє на засадах гуманізму, справедливості та досконалості.

Інтеграційні процеси мистецтва досконало досліджували науковці різних споріднених галузей наук - філософії, соціології, психології, педагогіки, мистецтвознавства тощо, водночас, ураховуючи складний, динамічний характер взаємозв'язків у соціокультурному просторі, постає потреба більш широкого огляду питань багаторівневої інтеграції у системі підготовки фахівців мистецьких спеціальностей у вищих навчальних закладах України відносно до зовнішніх, внутрішніх і дифузних рівнів функціонування культурно-мистецьких зв'язків сучасного соціуму.

Про інтегративні тенденції у розвитку науки як комплексу наукових дисциплін свідчать процеси взаємодії багатьох методологічних підходів, які виконують пояснювальні, праксеологічні, гносеологічні, світоглядні, організаційні, системовідтворювальні, проектно-моделюючі, стратегічні функції. На сучасному етапі широко використовуються поняття полікультурної освіти (К. Беннет, Дж. Бенкс, Л. Голік, В. Сршов, Е. Ільєнков, С. Каган, В. Сластьонін, Е. Холлінс, Є. Шиянов, В. Шадріков), поліхудожньої освіти (А. Бичко, В. Борисенко, Л. Левчук, Г. Онкович, Л. Масол, 
Н. Миропольска, О. Щолокова та ін.), поліхудожнього виховання (Г. Шевченко, Б. Юсов), полікультуралізму (Н. Москаленко), полікультурності (М. Бахтін, Я. Гулецька, П. Каптерев).

Проблеми синтезу, інтеграції та взаємозв'язків видів мистецтва і культури, питання функціонування системи видів мистецтва висвітлені багатьма дослідниками (М. Арановський, М. Бахтін, М. Бонфельд, В. Ванслов, Г. Григор'єва, Н. Дмитрієва, А. Зісь, А. Казін, Н. Крилова, Т. Ліванова, М. Лобанова, А. Лосєв, Л. Масол, Н. Миропольська, А. Михайлов, В. Михальов, О. Шевчук, В. Холопова та ін.). Методи використання інтеграційних процесів мистецтва в педагогіці знайшли місце в наукових працях таких дослідників і педагогів, як Д. Кабалевський, М. Каган, Л. Масол, Г. Падалка, О. Шевнюк, Г. Шевченко, Б. Юсов та ін.

У наукових дослідженнях комплексно використовуються прогресивні методики різних галузей науки: плідними визначились методи і підходи до вивчення мистецтва і музики, застосовані із лінгвістики, семантики, математики (Л. Александрова, А. Летичевський, К. Шушпанов), теорії інформації, теорії імовірності, структуралістики (Б. Гаспаров, І. Рудь, О. Соколов), дизайну і музичної семантики (М. Арановський, Г. Орлов, А. Фарбштейн) тощо.

Методологічна база використання інтеграційних механізмів мистецтва як чинників впливу на формування естетичних орієнтацій, світогляду, професійної компетенції студентів ВНЗ розглядається у нашому дослідженні стосовно системного, комплексного, діяльнісного підходів, які спрямовані сутності інтеграційних методів, способів, технологій у мистецтвознавчому та педагогічному аспектах, на розкриття сутності і змісту художньої інтеграції в мистецтві й культурі стосовно історичного, теоретичного, міжвидового та внутрішньовидового аспектів, та розглядають питання інтеграції мистецтва у ракурсі психологічних, пізнавальних, комунікативних, організаційних, креативних процесів у діяльності майбутнього вчителя та спеціаліста певної галузі. У мистецтвознавстві досліджено проблеми взаємодії, синтезу, інтеграції видів мистецтва з позицій міждисциплінарного, комплексного і системного підходів.

Мета статті полягає у визначенні рівнів і характерних ознак багаторівневої інтеграції в системі підготовки мистецьких спеціальностей у вищих навчальних закладах України.

Основними компонентами єдиної системи освіти в галузі мистецтва є загальна мистецька, мистецько-педагогічна і професійно-мистецька освіта. Безумовно, означені компоненти системи освіти в галузі мистецтва $є$ автономними, але міцно пов'язаними із мистецтвом як головним об'єктом професійно-мистецької і мистецько-педагогічної діяльності. Мистецтво є системою, яка постійно і стабільно розвивається у прогнозованих і непрогнозованих напрямках.

Підготовка фахівців мистецьких спеціальностей у вищих навчальних закладах України висуває необхідність досягнення комплексу цілей освітнього й соціокультурного простору, 3-поміж яких виокремимо:

- збереження і примноження культурно-мистецької спадщини України;

- створення системи концептуальних засад підготовки фахівців у галузі мистецтва щодо інтеграції мистецької освіти до єдиного європейського освітянського простору;

- створення ефективних умов підготовки фахівців мистецьких спеціальностей щодо наближення до світових стандартів і збереження мистецьких традицій України;

- формування особистісно-відповідального ставлення майбутніх митців і педагогів в галузі мистецтва до світу, природи, життя, творчості і мистецтва;

- формування вмінь i навичок майбутніх фахівців мистецьких спеціальностей до проективної детермінації особистого життя, мистецької, культуротворчої діяльності і майбутнього суспільства взагалі;

- досягнення стану багаторівневої інтеграції на основі інтеграції фундаментальних, культурологічних, художньо-мистецьких, професійно-спеціальних, мистецтвознавчих знань, науково-теоретичного, практично-діяльнісного досвіду, інтеграції традиційного, академічного й інноваційного досвіду педагогічних, художньо-мистецьких, соціально-проектних технологій, інтеграції видів мистецтва і видів творчої діяльності, інтеграції мистецьких завдань і забезпечення цілісності у процесі професійної підготовки фахівців мистецьких спеціальностей як умови створення поліінтеграційної моделі підготовки фахівців мистецьких спеціальностей;

- формування професійної системи компетенцій, компетентностей, знань, умінь і навичок майбутніх фахівці мистецької галузі за обраною спеціальністю;

- підготовка фахівців вищої кваліфікації у галузі мистецтва з урахуванням мистецьковидової і фахової специфіки, здатних до самовдосконалення, саморегулювання і саморозвитку; 
- визначення стратегії подальшого розвитку системи підготовки фахівців мистецьких спеціальностей у ВНЗ України щодо реалізації ідей і принципів єдиного європейського і світового освітянського і мистецького простору тощо.

Знакова роль у процесі професійної підготовки фахівців мистецьких спеціальностей належить інтеграції як багаторівневій системі внутрішніх і зовнішніх взаємозв'язків і взаємодій компонентів навчально-виховного процесу і соціокультурного середовища. Сутність інтеграції мистецтва й освіти полягає не в кількості запропонованих дослідниками, педагогами й методистами різних методів, методик, технологій, а в реальному результаті - у самому факті поступального розвитку суспільства та його окремих сегментів, у продуктивності методик, ефективності певних системних інтенцій, оптимізації освітнього процесу.

У філософському енциклопедичному словнику інтеграція тлумачиться як сторона процесу розвитку, яка пов'язана із об'єднанням у ціле різнорідних частин і елементів. Процеси інтеграції можуть виникати в рамках систем, які вже склалися. У цьому випадку ці процеси зумовлюють підвищення рівня цілісності й організованості цих систем [8, с. 214]. Також процеси інтеграції зумовлюють утворення нових систем із непов'язаних раніше елементів [8, c. 214]. До того ж окремі частини інтегрованого цілого можуть мати певний ступінь автономії [8, с. 214]. Наслідками інтеграційних процесів стає збільшення обсягів та інтенсивності взаємозв'язків і взаємодій між елементами тощо [8, с. 214].

У логічному словнику-довіднику М. Кондакова інтеграція визначається як об'єднання в цілісну єдність будь-яких елементів, відновлення будь-якої єдності тощо [3, с. 203]. Щодо теорії систем, М. Кондаков виокремлює стан взаємозв'язку окремих компонентів теми і процес, що зумовлює такий стан [3, с. 203].

Інтеграція культурна розглядається Б. Кононенко як процес поглиблення культурної взаємодії і взаємодії між державами, національно-культурними групами та історикокультурними галузями [4, с. 159]. Згідно з позицією Б. Кононенко, інтеграція культурна охоплює взаємодію між закладами культури, митцями і споживачами культури, а також, процеси угод між національними формами культури, між традиціями і новаціями і сприяє встановленню єдиної загальнолюдської системи цінностей [4, с. 159].

Інтеграція до глобалізованого суспільства пронизує всі щаблі процесу розвитку суспільства: від мегарівнів світової економіки, політики і культури до мікрорівнів особистого життя кожного члена суспільства. Кожна галузь науки і виробництва, завдяки інтеграційним технологіям, спроможна відбудовувати структуру будь-якого процесу й комбінувати зміст прогнозованого продукту стосовно запитам відповідних замовників - держави, господарства, суспільства, певної споживацької аудиторії тощо.

Така диференціація інтегративних інтенцій сучасного постіндустріального глобалізованого суспільства дозволяє говорити про поліінтегративний контекст мистецьких реалій сучасності. Багаторівнева інтеграція як ознака сучасних процесів стає важливою ознакою сучасного освітнього процесу.

Багатобічна система взаємодії різних видів мистецтва як особливий тип художніх зв'язків, пов'язана з загальними законами пізнання й художнього мислення, 3 прагненням зрозуміти світ людини, оскільки в мистецтві завжди створюється модель цього світу, але модель завжди ця своєрідна й унікальна, тому інтерпретація і тлумачення будь-якого художнього тексту завжди стає більш складним.

Інтеграція в мистецтві і сучасній культурі історично успадкована від самої синкретичної сутності мистецтва, що у стані генезису було єдиним нерозчинним феноменом розуміння світу існування людини. Успадкувавши ці іманентні риси, мистецтво створило велику диференційовану, розгалужену систему пізнання і відбиття світу, але єдність усіх видів мистецтва і художньої діяльності полягає в духовно-філософських, світоглядних основах буття і тих завданнях, які поставлені суспільством у процесі рефлексії й буттєвого сенсу існування людства на планеті.

Поняття інтеграції визначається О. Рудницькою як «взаємопроникнення мистецтв, вироблення спільного підходу до їх вивчення, спосіб поліхудожнього пізнання мистецьких явищ» [7, с. 130]. Проблеми інтеграції знань у контексті художнього мислення і сприймання розглядає О. Рудницька, яка стверджує, що врахування феномену художньої інтеграції у навчально-виховному процесі стає важливішою умовою розвитку художнього сприйняття у процесі підготовки фахівців мистецьких спеціальностей [7, с. 119]. Згідно 3 позицією 
О. Рудницькою, інтеграція знань у галузі мистецької освіти представляється як послідовність етапів опанування художньої мови і набуття досвіду її сприйняття [7, с. 121].

Спільність художнього мислення в мистецтві полягає в сукупності виразних i образотворчих можливостей художньої мови, що визначають цілісність створеного образу і складності спілкування із споживачами мистецтва. До основних категорій взаємодії видів мистецтва відносимо простір і час як нерозривні категорії, що відтворюють об'єктивне буття матеріально-духовного світу, синкретизм як первинну нерозчинну єдність форм опанування реалій буття, взаємодію як процес і результат встановлення взаємозв'язків у мистецькій діяльності і мистецтві, просторово-часові взаємозв'язки як основу формування художньообразної сфери засобами мистецтва, міжвидові й внутрішньовидові аспекти інтеграції мистецтв, що виявляються у творчій діяльності внаслідок дії механізмів цілісного впливу творів мистецтва на свідомість людини тощо [5].

Система вищої мистецької освіти $\epsilon$ частиною суспільно-культурної системи i підпорядковується відповідним організаційним структурам суспільства і влади, взаємодіє із організаціями й інституціями культури, освіти, мистецтва, бізнесу і здійснює вплив на розвиток своєї інфраструктури тощо. Тобто можна розглядати з різних позицій систему вищої мистецької освіти у просторі соціокультурної взаємодії відповідно до загальної чотирирівневої структури зовнішньо-внутрішніх зв'язків - мегарівень, макрорівень, мезорівень і мікрорівень функціонування системи вищої професійної мистецької освіти в суспільстві.

Мегарівень зовнішніх зв'язків щодо функціонування системи вищої мистецької освіти у суспільстві становлять світові організації, діяльність яких спрямована на врегулювання, підтримку і розвиток світової і європейської культури, мистецтва, освіти в галузі мистецтва. Завдяки діяльності міжнародних організацій українське мистецтво, культура, наука і освіта отримують потужну підтримку, що дозволяє діячам і працівникам культури і мистецтва, студентам і науковцям брати участь у міжнародних програмах, проектах тощо.

Макрорівень зовнішніх зв'язків щодо функціонування системи вищої мистецької освіти у суспільстві становлять державні організації, діяльність яких спрямована врегулювання, підтримку і розвиток культури, мистецтва, освіти у галузі мистецтва. Цей рівень представлено законодавчими документами: Конституція України, Бюджетний Кодекс України, Закон України «Про культуру», Закони України «Про освіту», «Про вищу освіту» «Про авторське право і суміжні права», «Про охорону культурної спадщини», «Про інноваційну діяльність», «Про позашкільну освіту», «Про кінематографію», «Про рекламу», «Про театри і театральну справу», «Про інформацію», Матеріали Підсумкової колегії МОН України «Вища освіта України - європейський вимір: стан, проблеми, перспективи» тощо.

Мезорівень зовнішніх зв'язків щодо функціонування системи вищої мистецької освіти в суспільстві охоплює заклади освіти, мистецтва й культури, які виконують функції надання освітніх послуг з професійної підготовки фахівців мистецьких спеціальностей, а також суспільні, культурно-мистецькі організації різних форм власності, діяльність яких сприяє підготовці фахівців мистецьких спеціальностей (громадські й благодійні організації, фонди, мистецькі й творчі об’єднання, клуби, рекламні та творчі агенції, позашкільні заклади, дитячі установи, оргкомітети фестивалів, конкурсів тощо). Діяльність наведених організацій полягає в наданні відповідними організаціями баз практики, у реалізації сумісних творчих, мистецьких, соціокультурних проектів, у творчих контактах, що сприяє ефективному розвитку системи підготовки фахівців мистецьких спеціальностей.

Мікрорівень - рівень зовнішньо-внутрішніх зв'язків системи освіти в галузі мистецтва, систем професійної підготовки фахівців мистецьких спеціальностей визначає співвідношення, співіснування, кореляції в організації освітніх послуг на засадах міждисциплінарності, інтеграції.

Кожен із наведених рівнів функціонування системи вищої мистецької освіти в суспільстві відповідно поділяється на споріднені підсистеми, компоненти яких інтегруються до системи вищої професійної мистецької освіти відповідно до характеру взаємодії, рівнів сумісництва, соціокультурних зв'язків, функціональних взаємозв'язків, матеріально-технічного забезпечення, відповідності умов освітнього процесу, відповідності завдань діяльності тощо.

Підготовка фахівців мистецьких спеціальностей у вищих навчальних закладах України спрямована на професіоналізацію освітнього процесу відповідно до вимог сучасного суспільства щодо формування конкурентоспроможних якостей особистості, з урахуванням 
індивідуалізації процесу підготовки особистості до професійної діяльності на основі створення структури мистецько-освітнього процесу 3 урахуванням зовнішніх, внутрішніх і змішаних рівнів взаємозв'язків мистецтва, культурно-мистецької, професійно-мистецької, художньотворчої і мистецько-педагогічної практики у процесі багаторівневої інтеграції компонентів системи освітнього і соціокультурного простору сучасності. У зв'язку з вище викладеним виникає потреба розглядати процес професійної підготовки фахівців мистецьких спеціальностей як поліінтегровану багаторівневу систему, компоненти якої повинні динамічно розпредмечувати внутрішній культурологічний зміст структури особистості, враховуючи різноманітні можливості застосування професійного досвіду сучасного митця в суспільстві.

Перспективи подальшого дослідження становлять визначення методології багаторівневої мистецько-освітньої інтеграції та стратегій подальшого розвитку системи підготовки фахівців мистецьких спеціальностей у вищих навчальних закладах України.

\section{Література}

1. Большая советская энциклопедия (в 30 томах) / гл. ред А. М. Прохоров. - [Изд. 3-е.]. - М.: Советская энциклопедия, 1972. - Т. 10. - Ива-Италики, 1972. - 592 с., с илл. 2. Великий тлумачний словник сучасної української мови / уклад. і голов. ред. В. Т. Бусел. - К. : Ірпінь: ВТФ «Перун», 2007. 1736 с.: іл. 3. Кондаков Н. И. Логический словарь-справочник / Н. И. Кондаков. - М.: Наука, 1975. 720 с. 4. Кононенко Б. И. Большой толковый словарь по культурологии / Б. И. Кононенко. - М.: ООО «Издательство «Вече 2000», ООО «Издательство АСТ», 2003. - 512 с. 5. Пономарьова О. М. Деякі аспекти художньої інтеграції мистецтв у формуванні музично-естетичних орієнтацій майбутніх учителів / О. М. Пономарьова. - Педагогічні науки: [зб. наук. праць]. - Херсон: Вид-во ХДУ, 2005. Вип. 39. - С. 313-315. 6. Рудницька О. П. Педагогіка: загальна та мистецька / Оксана Петрівна Рудницька. - К., 2002. - 270 с. 7. Падалка Г. М. Педагогіка мистецтва (Теорія і методика викладання мистецьких дисциплін) / Г.М. Падалка. - К. : Освіта Україна, 2008. - 274 с. 8. Философский энциклопедический словарь / редкол. С. С. Аверинцев, Э. А. Араб-Оглы, Л. Ф. Ильичев и др. - [2-е изд.]. - М.: Сов. энциклопедия, 1989. - 815 с.

УДК 316.346.2:316.356.2.37.011.3

Ганна Приходько

\section{РОЛЬ ГЕНДЕРНИХ СТЕРЕОТИПІВ У КОНТЕКСТІ ДОСЛІДЖЕННЯ ПРОБЛЕМ СІМЕЙНОГО ВИХОВАННЯ}

Приходько Г. В. Роль гендерних стереотипів у контексті дослідження проблем сімейного виховання.

У статті розглянуто роль гендерних стереотипів у контексті теорії соціального конструювання статі. 3'ясовано, що такі стереотипи зумовлюють зміст, принципи та методи сімейного виховання, визначають ступінь залучення батьків до вихованнчя та особливості ставлення загалом до дітей залежно від їхньої статі.

Ключові слова: гендер (соціальна стать), біологічна стать, гендерний підхід, гендерні стереотипи, сімейне виховання.

Приходько А. В. Роль гендерных стереотипов в контексте исследования проблем семейного воспитания.

Статья посвящена раскрытию роли гендерных стереотипов в контексте теории социального конструирования пола. Выяснено, что такие стереотипы определяют содержание, принципы и методы семейного воспитания, степень участия родителей в воспитании, их отношение в целом к детям в зависимости от их пола.

Ключевые слова: гендер (социальный пол), биологический пол, гендерный подход, гендерные стереотипы, семейное воспитание.

Prihodko A. V. The gender stereotypes role in the context of family education problems.

The article is devoted to the role of gender stereotypes. According to the text gender stereotypes are influences over the contents, principles and methods of the family education; determines the degree of parents' participation in this process and there relations with boys and girls.

Key words: gender, sex, gender approach, gender stereotypes, social-cultural nature, family education. 